\title{
ECP 画像解析による結晶丕測定方法*
}

\author{
吉冨康成** 太田国照*** 菅 洋三** \\ 中山 正 $^{* *}$ 高橋延幸****
}

J. Japan Inst. Metals, Vol. 55, No. 1 (1991), pp. 22-28

A Method for Strain Measurement using ECP Image Analysis*

Yasunari Yoshitomi**, Kuniteru Ohta***, Yozo Suga**,
Tadashi Nakayama** and Nobuyuki Takahashi****

A method for strain measurement by Electron Channelling Pattern (ECP) Image analysis has been newly developed. The sharpness of ECP, which is defined by the ratio of sharp pseudo-Kikuchi lines in ECP image, is used as a parameter describing the remaining strain. Fe-3.25\% Si alloy single crystal and polycrystal were used as test specimens. Strain changes during deformation and recrystallization were measured by this method and compared with the hardness and line broadening of X-rays. The main results obtained are as follows.

(1) The sharpness of ECP decreased as strain was increased. This method is useful for measuring the strains of less than $15 \%$ cold reduction and less than $20 \%$ tensile elongation. And its strain sensitivity is larger for the smaller strains than that of line broadening of X-rays.

(2) The sharpness of ECP was influenced by the initial crystal orientation before deformation. This phenomenon was specially recognized in the case of the smaller strains, indicating that the accumulated strain is mainly influenced by the initial crystal orientation before deformation.

(3) The sharpness of ECP was increased during recrystallization. The fraction of a change of the sharpness of ECP during recrystallization was more significant than those of hardness and line broadening of X-rays.

(4) It is believed that this method is useful for analyzing the crystal orientation dependence of the accumulated strain and a decrease of strain during recovery and recrystallization, as well as the inhomogeneity of strain in the grain interior and near the grain boundary.

(Received August 13, 1990)

Keywords: strain measurement, scanning electron microscope, electron channelling pattern, electron channelling pattern image analysis

I . 緒言

雨の測定は, 加工, 回復，再結晶，集合組織等の研究に おいて重要であり ${ }^{(1)}$, 従来からいくつかの方法が用いられ てきた。歪の指標として, 硬度, X 線の回折線の幅広が りが一般に用いられているが, 硬度は固溶元素, 析出物の 影響を受けやすく，X 線の場合は測定領域が広い(>1000 $\mu \mathrm{m} \phi)$ ため, いずれも微小領域 $(<100 \mu \mathrm{m} \phi)$ の歪を精度よ く測定するには，不十分である.

一方，結晶質材料に歪が加わると Electron Channelling Pattern (ECP)が不鮮明となる現象を利用し, 特定の擬菊
池線のコントラストをパラメーターとして，歪を測定 する研究が行われてきた(2)-(10). Scanning Electron Microscope (SEM)を用いて, 結晶質材料に電子ビームを 角度走査すると，Bragg 反射条件を満たす入射角度で channelling 現象を起こし，多くの擬菊池線からなる ECP が得られる ${ }^{(11)}$. ECP は, 試料の $3 \mu \mathrm{m} \phi$ 程度の領域で測 定可能なので(12)，結晶の粒内，粒界近傍での歪の不均一 性の解析にも適用できる。しかし，出現する擬菊池線の種 類が結晶方位によって異なるため, 特定の擬菊池線に着目 する従来の方法(2)-(10)をすべての結晶方位に適用すること は不可能である(13). 更に, 1 つの擬菊池線に着目しても, そのコントラストが SEM 像の位置(入射電子ビームの走

* 1988年11月日本金属学会秋期大会に発表

** 新日本製鉄(侏)第三技術研究所電磁鋼研究センター (Electrical Steel Lab., R \& D Laboratories III, Nippon Steel Corporation, Kitakyushu)

*** 新日本製鉄侏 エレクトロニクス研究所半導体材料研究センター(Semiconductor Materials Research Lab., Electronics R \& D Laboratories, Nippon Steel Corporation, Hikari)

**** 新日本製鉄侏)第三技術研究所 (R \& D Laboratories III, Nippon Steel Corporation, Kitakyushu) 
查角度)で異なるため，コントラスト測定が容易でない(13)

そこで，すべての結晶方位に対して歪を測定するため， ECPの中の鮮明な領域の面積率をパラメーターとして, 歪量を測定する試みがなされた ${ }^{(14)}$. 本報では，画像解析 によって，ECPの中の鮮明な擬菊池線の割合 (ECP の鮮 明度)を評価し，これによって，結晶歪を測定する方法を 開発し (15), 加工, 再結晶での䄳変化を測定し, 硬度, $\mathrm{X}$ 線の回折線の幅広がりの結果と比較検討した.

\section{II． ECP 画像解析による結晶歪測定方法}

Fig. 1 に解析のフローを示す. 解析は(1)画像入力, (2) 濃淡画像処理，(3)二值化，(4)二値画像処理，(5)測定からな る。

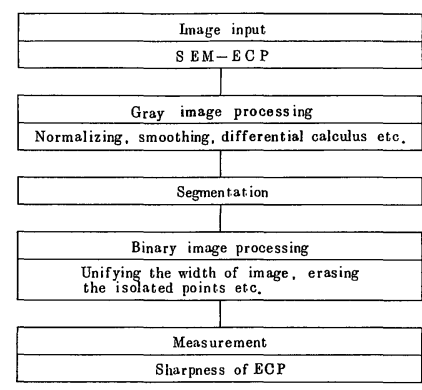

Fig. 1 Flow chart of ECP image analysis.

\section{1. 画像入力}

ECP 像を SEM から画像解析機に平均加算入力する. この入力方法により ECP 像の白色雑音が軽減される。

\section{2. 濃淡画像処理}

$(1) \rightarrow(6)$ の順で濃淡画像処理を行い，擬菊池線が強調され た画像を得る。

(1) 平滑化

中間值フィルターで入力画像をスムージングする.これ により，擬菊池線の鮮明さを保ちつつ，入力画像の雑音が 減少される.

(2) 濃淡レベルの規格化

対象画像の濃淡レベルの最小値, 最大値が各々画像解析 機の濃淡レベルの下限值，上限值になるように線形変換す る.これにより, SEM の作動状態の変動等による画像の 濃淡レベルの変動が軽減される。

（3）選択的局所平均化

対象画像に選択的局所平均化を行う。これにより, 濃淡 レベルの規格化で強調された雑音が減少される.
(4) 微 分

対象画像に Sobel フィルター(16)で 2 次元微分を行う. これにより，擬菊池線の部分が高い濃淡レベルを有する画 像(微分画像)が得られる.

(5) 微分画像の強調

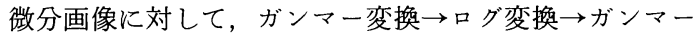
変換を行う。これにより，擬菊池線が強調される。

(6) 平滑化

中間值フィルターで対象画像をスムージングする.これ により，微分により強調された雑音が減少される。

\section{3. 二值化}

固定しきい值法により二值化を行う。これにより，鮮明 な擬菊池線を含む領域が抽出される。

\section{4. 二值画像処理}

(1) $\rightarrow(3)$ の順で二值画像処理を行い，鮮明な擬菊池線が抽 出された画像を得る.

（1）孤立点除去，図形の膨張，収縮

孤立点除去を行う。これにより，鮮明な擬菊池線を含ま ない面積の小さい領域が除去される，次に，図形の膨張 $\rightarrow$ 収縮を行う。これにより，Bragg 反射条件を満たす入射 角度の前後で形成される鮮明な擬菊池線を挾む 2 つ領 域 (2 次元微分が高い領域)が合体し，鮮明な擬菊池線を内 部に含む領域が形成される.

(2) 図形の平滑化，穴埋め

濃淡レベルの平滑化 $\rightarrow$ 二值化により図形の平滑化を行 う。これにより，鮮明な擬菊池線を含む領域が線状領域に 近づく，次に，図形の穴埋めを行う。これにより，鮮明な 擬菊池線を含む領域の中にある欠落部が埋められる.

(3) 細線化，図形の膨張

田村の方法 ${ }^{(17)} に よ り$ 細線化を行い, 次に, 図形の膨張 を行う。これにより，一定幅の線で構成された画像(鮮明 な ECP)が得られる。そして，これらの各線を鮮明な擬菊 池線と判定する.

\section{5. 測 定}

以下の式で定義される ECP の鮮明度 $(S)$ を測定する.

$$
S=\Sigma L_{\mathrm{i}} \times W / A(\%)
$$

ここで, $L_{\mathrm{i}}: \mathrm{ECP}$ 画面内の鮮明な擬菊池線の長さ， $W$ : ECP 画面内の鮮明な擬菊池線の幅(定数), $A$ : ECP 画面 の面積 (定数) である。 $W$ と $A$ は定数なので, ECP の鮮 明度 $(S)$ は ECP 画面内の鮮明な擬菊池線の総長の定数倍 となる．鮮明な擬菊池線は，画面上では，実際には断続的 な曲線なので，各曲線の総長を測定する，各曲線(鮮明な 擬菊池線)の総長 $\times$ 各曲線の幅 $/ \mathrm{ECP}$ 画面の面積は上記一 連の画像処理で形成された画像(鮮明な ECP)の曲線の面 積率である。この ECP の鮮明度は，ECP の中の鮮明な擬 菊池線の割合を示す量である。 


\section{III. 適用 例}

\section{1. 供試材}

加工䟚解析の目的で, $\mathrm{Fe}-3.25 \% \mathrm{Si}$ 合金の単結晶焼鈍 板，多結晶焼鈍板(粒径 10～50 $\mu \mathrm{m}$ ) にロール径 $120 \mathrm{~mm}$ の圧延機で圧下率 0 17\%(1 パス)の冷間圧延を施し，歪 の異なる種々のサンプルを作成した。サンプルの元厚は $0.36 \mathrm{~mm}$ であり，ロールにはパーム油を施し圧延した。 また，上記多結晶焼鈍板に引張試験機で伸び率 0～20\%の 歪を加えたサンプルも合わせて作成した，冷間圧延の圧延 方向と引張方向は同一にした，加工前の単結晶焼鈍板，多 結晶焼鈍板の $\{100\}$ 極点図を各々 Fig. 2, Fig. 3 に示す.

単結晶の方位としては，蓄積歪が大きく異なることが予想 される(110) [001]と（100）[011]を選んだ．また，多結晶 焼鈍板はランダムに対して $\{100\}$ に近い方位がやや多い集 合組織を有している.

また，再結晶での歪解放過程の解析の目的で， Fe$3.25 \% \mathrm{Si}-0.01 \% \mathrm{C}$ 合金の $2.3 \mathrm{~mm}$ 厚の熱延板を $1273 \mathrm{~K}-$ $300 \mathrm{~s}$ の焼鈍後，約 $88 \%$ の圧下率で $0.285 \mathrm{~mm}$ 厚まで冷間 圧延し, 次いで, $20 \mathrm{~K} / \mathrm{s}$ で $1173 \mathrm{~K}$ まで昇温する過程で, $773 \mathrm{~K}$ から $1173 \mathrm{~K}$ までの各温度で，サンプルを炉から引 き出し空冷して，昰の異なる種々のサンプルを作成した.

\section{2. 測定方法}

歪の異なる種々のサンプルをフッ酸と過酸化水素水の水 溶液で板厚中心まで片面から化学研磨して，ECP の鮮明 度測定に供した．化学研磨後の試料の表面は，鏡面状態に あった．化学研磨後の試料を，デシケーターに入れて保存 し，ECP の鮮明度測定時でも，試料の表面は，鏡面状態 にあった，単結晶サンプル，多結晶サンプルについて，
各々 10 点(圧延方向から $\pi / 12 \mathrm{rad}$. 方向 2 点 $\times$ その方向之 $\pi / 2 \mathrm{rad}$. 方向 5 点, 各 $100 \mu \mathrm{m}$ 間隔)，50点(圧延方向か ら $\pi / 12 \mathrm{rad}$. 方向 5 点 $\times$ その方向と $\pi / 2 \mathrm{rad}$. 方向 10 点， 各 $1000 \mu \mathrm{m}$ 間隔)で ECP の鮮明度を測定した.

$\mathrm{SEM}-\mathrm{ECP}$ (反射電子像)の測定は，加速電圧 : $35 \mathrm{kV}$, 試料電流: $9 \times 10^{-9} \mathrm{~A}$, 作動距離(W.D.) : $8 \mathrm{~mm}$, ロギン グ角 : $\pm 8 \times(\pi / 180) \mathrm{rad}$.の条件で行った． ECP の鮮明度 の測定は，前記の方法で行った。 また，従来の昰測定法と の比較のために, 冷間圧延を施した多結晶サンプルについ ては，X 線 ((200) 回折線)の半価幅を測定し, 冷間圧延を 施した後昇温した多結晶サンプルについては， $\mathrm{X}$ 線 ((200) 回折線)の半価幅, ビッカース硬度，再結晶率を測

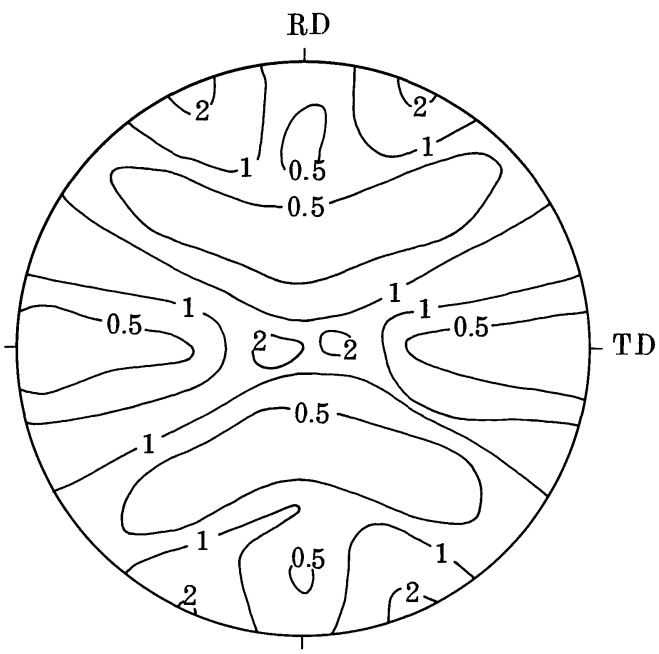

Fig. $3\{100\}$ pole figure for $\mathrm{Fe}-3.25 \% \mathrm{Si}$ alloy polycrystal specimen. (a) $(110)[001] \quad \mathrm{RD}$

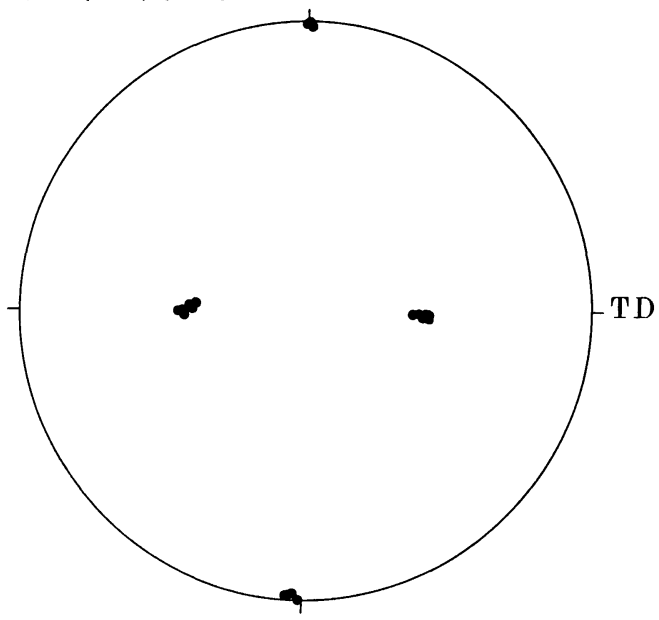

(b) $(100)[011] \quad \mathrm{RD}$

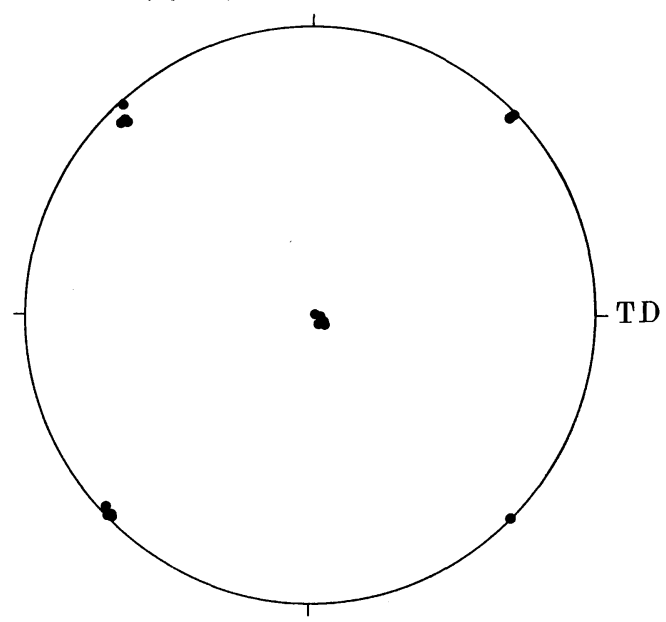

Fig. $2\{100\}$ pole figures for Fe-3.25\% Si alloy single crystal specimens. 


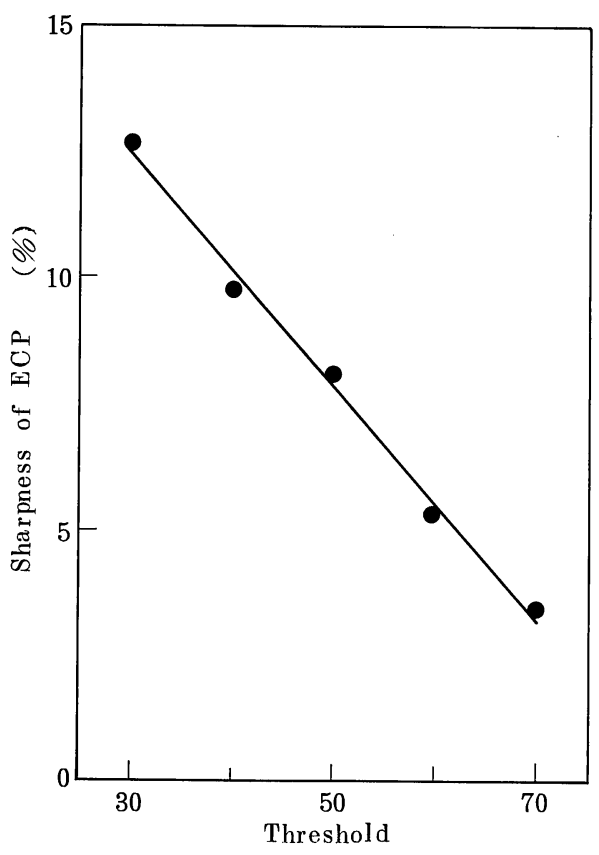

Fig. 4 Influence of analysing condition on the sharpness of ECP from Fe-3.25\% Si alloy (110) [001] single crystal.

定した。ここで，X 線の半価幅の測定は，Mo 管球を用 い, 加速電圧 : $40 \mathrm{kV}$ ，フィラメント電流 : $20 \mathrm{~mA}$ の条件 で行った．ビッカース硬度は，加重 $1 \mathrm{~kg}$ で測定した 5 点 の中間値 3 点の平均から求めた。再結晶率は, SEM で得 られる Electron Channelling Contrast (ECC)像の写真に 対するポイントカウント法(100点)による目視判定から求 めた。また，ECPの鮮明度の物理的意味を明らかにする ため, 引張変形を施した多結晶サンプルについては, 変形 応力と ECP の鮮明度の関係を調查した。

ECP の鮮明度は, ECP の中の鮮明な擬菊池線の割合を 示す量であるが，擬菊池線が鮮明かどらかの判定基準は， 二值化のしきい值である. Fig. 4 に示すように，二值化 のしきい值が高い程, ECP の鮮明度の值は低くなる。そ こで, 基準となるサンプルの ECP の鮮明度で割った ECP の鮮明度の相対値を歪の指標として用いた。本研究 では, この二值化のしきい值として，特にことわらない限 り50を用い, 一部のサンプルについては，50以外の二値 化のしきい值を用いた測定も合わせて行った。

なお，ECP の鮮明度の測定には, SEM : JSM-840, 画 像解析機 : TOSPIX-IIを用いた。

\section{3. 測定結果}

(1) 加工歪

単結晶サンプルを用い, 本法の画像解析により抽出した ECPの中の鮮明な擬菊池線に対する歪量の影響を Fig. 5
に示す。また，単結晶に冷間圧延で加えた歪量と ECP の 鮮明度の関係を Fig. 6 に示す. Fig. 5 に例示した鮮明な 擬菊池線の総長の定数倍が各サンプルの ECP の鮮明度で ある. 冷間圧延の圧下率 $17 \%$ 以下の加工歪において, 歪 を加えることにより，ECP の鮮明度は単調減少したが， その程度は結晶方位に依存した。（110）[001]方位単結晶 の場合には, ECP の鮮明度は, 圧下率 $1.5 \%$ の歪を加えた だけで急激に減少し，その後は緩やかに減少した。他方， (100) [011]方位単結晶の場合には，歪を加えることによ る ECP の鮮明度の減少は緩慢であった。 また，30〜70の 範囲の二值化のしきい值を用いた場合, Fig. 6 の関係と大 差のない結果が得られた.

次に，多結晶に拈ける測定結果を示す．以下で示す ECP の鮮明度は, 種々の方位の結晶粒各 50 個の測定値の 平均値である.

多結晶に括ける ECP の鮮明度, X 線 ((200) 回折線)の 半価幅に対する冷間圧延で加えた昰量の影響を Fig. 7 に 示す． ECP の鮮明度は，圧下率1.5\%の歪を加えただけで 急激に減少し，その後は圧下率 $15 \%$ の歪に到るまで緩や かに減少したが, X 線 ((200) 回折線)の半価幅は, 圧下率 15\%以下の歪の全範囲で, 歪を加えることにより緩やか に増加した.

多結晶に引張で加えた歪量と ECP の鮮明度の関係を Fig. 8 に示す．ECP の鮮明度は，微小な歪を加えただけ で急激に減少し，その後は伸び率20\%の歪に到るまで緩 やかに減少した.

上記の加工歪に対する測定結果は, SEM-ECP の条件が 加速電圧 : $35 \mathrm{kV}$ の場合であり, 加速電圧が $35 \mathrm{kV}$ より 低い場合には測定しうる歪の上限が上記の値より低まり， 加速電圧が $35 \mathrm{kV}$ より高い場合には，測定しうる歪の上 限が上記の値より高まると考えられる。

\section{(2) 変形応力と ECP の鮮明度の関係}

Fig. 9 に示すよらに, 引張変形時の変形応力の増加に 伴いECP の鮮明度は減少した。

本法においては，現出した ECP 画面のすべての擬菊池 線のコントラストの平均的な值(ECP の鮮明度)を, 画像 解析で求めている. 特定の擬菊池線のコントラストをパラ メーターとして, 歪を測定する方法において, 試料の転位 密度の増加に伴いこのコントラストは減少する(3). また， 弾性変形においては，このコントラストはほとんど变化し ない(18)。また，転位密度の $1 / 2$ 乗と変形応力とは比例関係 にあること (19) を考慮すると，本法で定義した ECP の鮮明 度は転位密度の増加に伴い単調減少する量と考えられる.

加工による蓄積歪(転位密度)は結晶の方位により異な る(20)(21). Fig. 6 に示すように，(110)[001]方位単結晶の 場合には，歪を加えると ECP の鮮明度は急激に減少した が，（100）[011]方位単結晶の場合には，昰を加えること によるECP の鮮明度の減少は緩慢であった。これは, (110) [001]方位の方が(100) [011]方位よりも加工による 

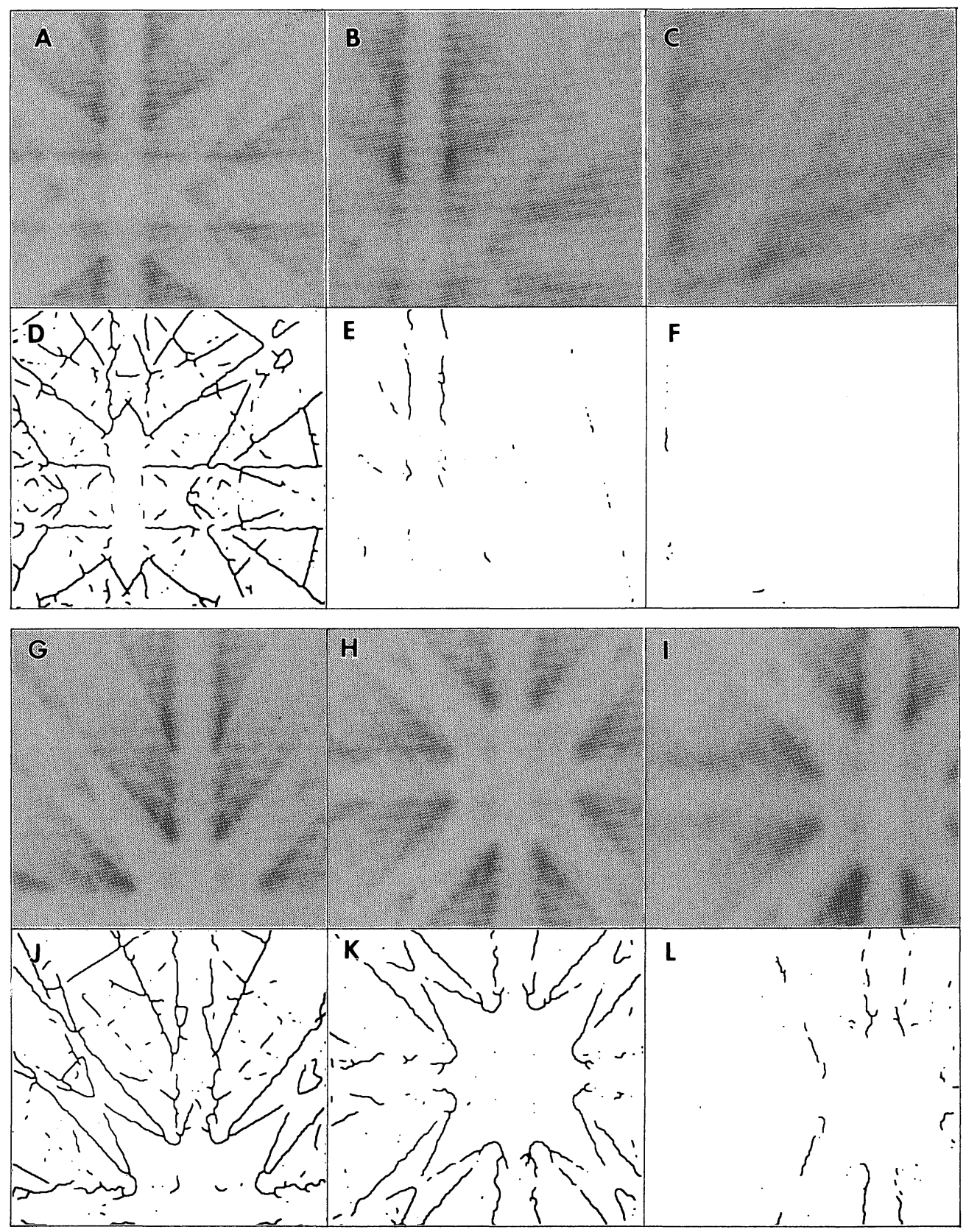

Fig. 5 Influence of strain on observed ECP and modified ECP by image analysis. Specimens: Fe-3.25\% Si alloy single crystals at the midplane. A, B, C, D, E, F: (110) [001]. G, H, I, J, K, L: (100) [011]. A, B, C, G, H, I: ECP. D, E, F, J, K, L: modified ECP by image analysis. A, D, G, J: without cold rolling. B, E, H, K: $1.5 \%$ cold rolling. C, F, I, L: $17 \%$ cold rolling.

蓄積歪(転位密度)が大きいことによると考えられる。

\section{(3) 再結晶での歪解放}

約 $88 \%$ の圧下率で冷間圧延した多結晶板を，加熱した 場合の昇温過程での再結晶, ECP の鮮明度, 硬度, X 線 ((200) 回折線)の半価幅の挙動を Fig. 10 に示す. 再結晶 の進行に伴いECP の鮮明度は急激に増加したが, 硬度,
$\mathrm{X}$ 線 ((200) 回折線)の半価幅の減少は, ECP の鮮明度の増 加よりも緩慢であった．上記の ECP の鮮明度の挙動は, 再結晶に伴う転位密度の減少によるものと考えられる。な お, 回復の進行に伴い, 硬度, X 線 ((200) 回折線)の半価 幅は緩やかに減少したが, ECP の鮮明度は, 測定場所に より多少の変動があるものの，本測定条件ではほぼ 0 に 


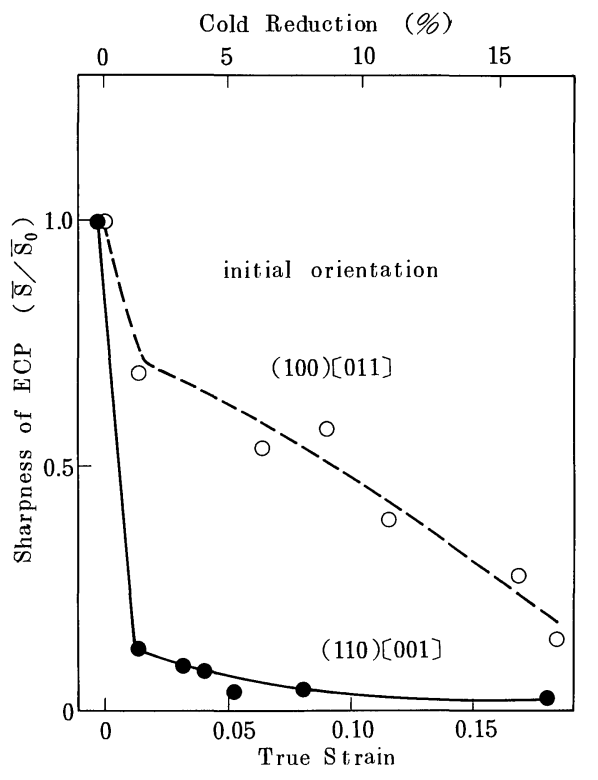

Fig. 6 Influence of strain on the sharpness of ECP for $\mathrm{Fe}-3.25 \% \mathrm{Si}$ alloy single crystal at the midplane. $S$ : sharpness of ECP. $S_{0}$ : value of $S$ without deformation.

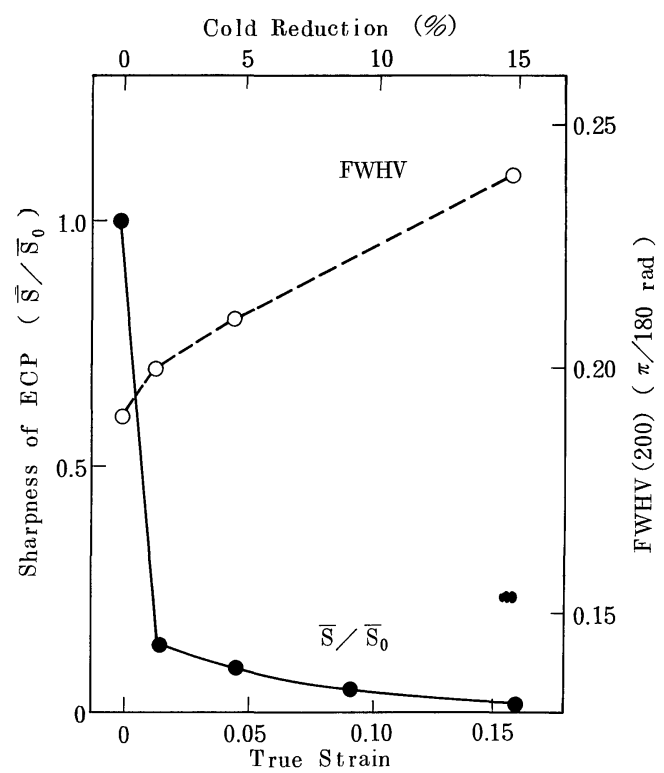

Fig. 7 Influence of strain by cold rolling on the sharpness of ECP and FWHV (200) by X-rays at the midplane. Specimen: Fe-3.25\% Si alloy polycrystal. $S$ : sharpness of ECP. $S_{0}$ : value of $S$ without deformation.

近い値であった。回復段階での歪解放過程を ECP の鮮明 度で正確に評価するには, 加速電圧, W.D. 等の SEM 作 動条件, ECP 入力時の画像の平均加算の回数, 二值化の しきい值等の画像解析条件を検討する必要がある.

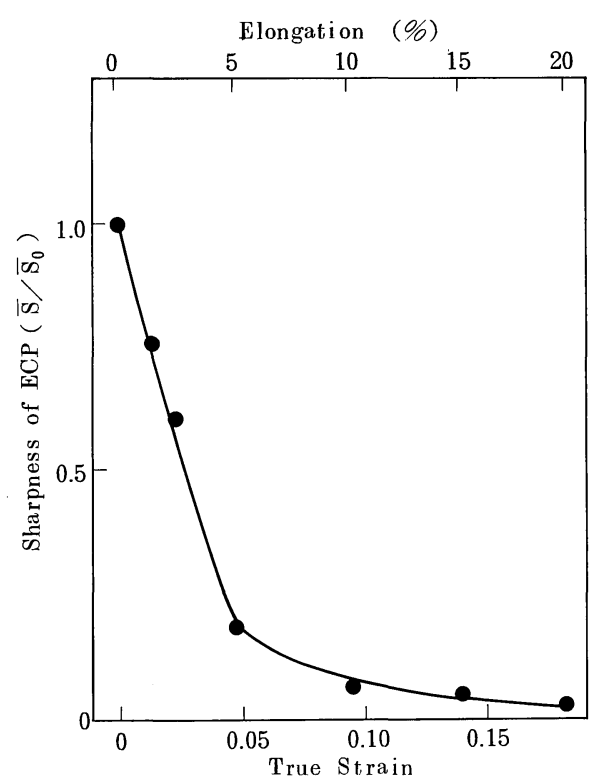

Fig. 8 Influence of tensile strain on the sharpness of ECP at the midplane. Specimen: $\mathrm{Fe}-3.25 \% \mathrm{Si}$ alloy polycrystal. $S$ : sharpness of ECP. $S_{0}$ : value of $S$ without deformation.

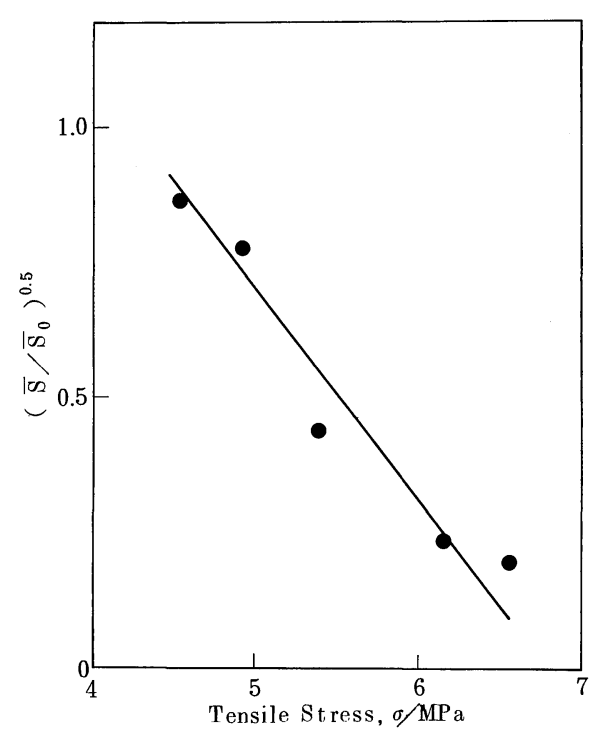

Fig. 9 Relation between tensile stress and the sharpness of ECP $(S)$ at the midplane. Specimen: Fe$3.25 \% \mathrm{Si}$ alloy polycrystal. $S_{0}$ : value of $S$ without deformation.

\section{N. 結論}

画像解析によって, ECPの中の鮮明な擬菊池線の総長 (ECP の鮮明度)を計測し, これによって, 結晶歪を測定 

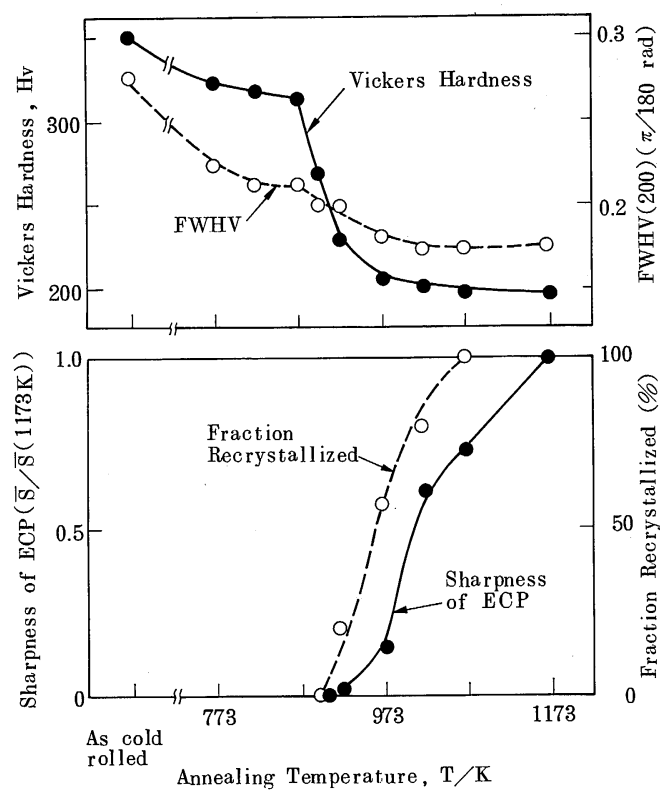

Fig. 10 Changes in the sharpness of ECP, the fraction of recrystallized area, Vickers hardness and FWHV (200) by X-rays at the midplane during heating at a rate of $20 \mathrm{~K} / \mathrm{s}$ after $88 \%$ cold rolling. Specimen: Fe-3.25\% Si alloy polycrystal. $S$ : sharpness of ECP.

する方法を開発した．Fe-3.25\% Si 合金の単結晶，多結晶 を供試材とし，加工，再結晶での歪変化を本法を用いて測 定し, 硬度, X 線の回折線の幅広がりの結果と比較検討 した．得られた知見を以下に示す。

（1）歪を加えると ECP の鮮明度は単調減少した．本法 は，冷間圧延の圧下率で15\%以下，引張の伸び率で $20 \%$ 以下の歪の測定に有効であり，圧下率で $1.5 \%$ 程度の微小 歪に対する感度は，X 線の幅広がりより高い。上記の測 定しうる歪の上限値は, SEM-ECP の条件が加速電圧 : $35 \mathrm{kV}$ の場合であり, 加速電圧が $35 \mathrm{kV}$ より低い場合に は測定しうる歪の上限が上記の值より低まり, 加速電圧が $35 \mathrm{kV}$ より高い場合には, 測定しうる歪の上限が上記の值 より高まると考えられる。

（2）ECPの鮮明度は初期方位の影響を受けた。この影 響は加工歪が小さい場合に顕著であった．この現象は主に 蓄積歪が初期方位の影響を受けることによるためと考えら れる。

（3）再結晶の進行に伴いECP の鮮明度は急激に増加し た.そして, 再結晶の進行に伴ら硬度, $\mathrm{X}$ 線の幅広がり
の変化よりも ECP の鮮明度の変化の方が顕著であった.

(4) ECP の鮮明度は転位密度の増加に伴い単調減少す る量と考えられる。

（5）本法は，蓄積昰の結晶方位依存性，回復，再結晶で の歪解放, 結晶の粒内, 粒界近傍での歪の不均一性等の解 析に有効と考兄られる.

本研究のご指導を頂きました長嶋晋一博士に感謝致しま すＥＥに関するご指導を頂きました原勢二郎博士， 清水 亮博士に感謝致します. ECP の測定にご協力を頂き ました有吉富雄氏に感謝致します。

\section{文献}

（1）例えば，武智 弘：鉄と鋼， 70(1984), 5 .

(2) D. C. Joy and D. E. Newbury: in SEM/1971, Proceedings of the 4th Annual SEM Symposium, ed. O. Johari, IITRI, Chicago, Illinois, (1971), 113.

( 3 ) R. Stickler, C. W. Hughes and G. R. Booker: in SEM/1971, Proceedings of the 4th Annual SEM Symposium, ed. O. Johari, IITRI, Chicago, Illinois (1971), 473.

(4) E. M. Schulson: Phys. Status Solidi (b), 46(1971), 95.

( 5 ) D. L. Davidson: in SEM/1974, Proceedings of the 7th Annual SEM Symposium, ed. O. Johari, IITRI, Chicago, Illinois, (1974), 927.

(6) A. W. Ruff: Wear, 40(1976), 59.

( 7 ) D. L. Davidson, J. Lankford, T. Yokobori and K. Sato: Int. J. Fracture, 12 (1976), 579.

( 8 ) D. L. Davidson: in $S E M / 1977$, Proceedings of the 10th Annual SEM Symposium, ed. O. Johari and I. Corvin, IITRI, Chicago, Illinois (1977), 431.

( 9 ) D. L. Davidson: Scan. Electron Microsc., (1981), 373.

(10) R. C. Farrow and D. C. Joy: Scan. Electron Microsc., (1981), 397.

(11) D. G. Coates: Phil. Mag., 16(1967), 1179.

(12) S. Nakagawa: JEOL NEWS 24E-1, 7 (1986), 7.

(13) D. L. Davidson: Int. Metals Reviews, 29(1984), 75.

（14）舟木秀一, 谷野 満：日本電子顕微鏡学会関東支部 学術講演会, (1988), 22.

（15）吉富康成，太田国照，舟木秀一：日本特許出願公開 平 $1-182726$.

(16) 松山隆司：コンピューター画像処理入門,（田村 秀行監修)，総研出版，(1985), 120.

（17）田村秀行, 森 健一: 信全大, 1539 (1974), 1390 .

(18) D. L. Davidson: J. Mater. Sci. Lett., 1(1982), 236.

(19) 例えば, Z. S. Basinski and S. J. Basinski: Phil. Mag., 9 (1964), 51.

(20) I. L. Dillamore, C. J. E. Smith and T. W. Watson: J. Meter. Sci., 1(1967), 49.

(21) H. Takechi, H. Katoh and S. Nagashima: Trans. Met. Soc. AIME, 242 (1968), 56. 